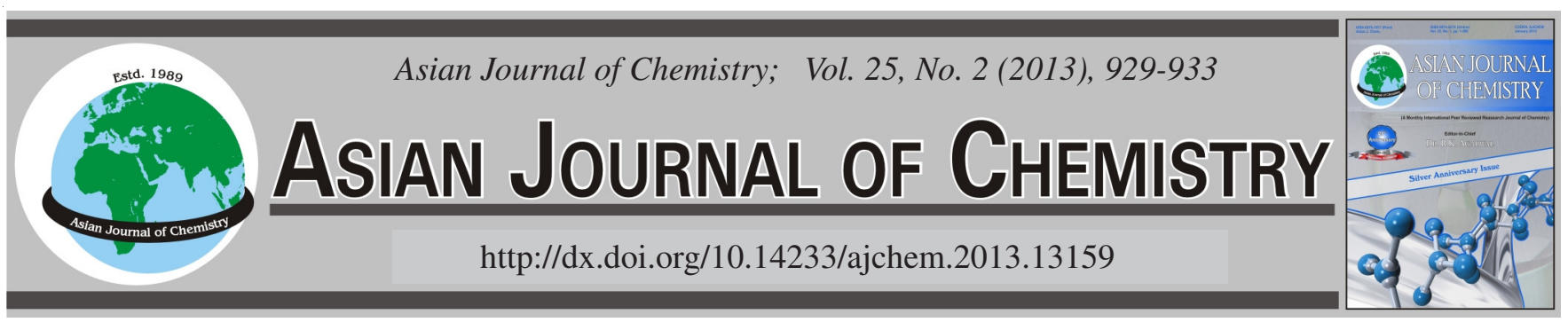

\title{
Comparative Chemical Composition of $n$-Hexane and Ethanol Extractives from The Heartwood of Black Locust
}

\author{
Seyyed Khalil Hosseinihashemi , V Ahidreza SAFdari and Siavash Kanani
}

Department of Wood Science and Paper Technology, Karaj Branch, Islamic Azad University, Karaj, Iran

*Corresponding author: E-mail: hashemi@kiau.ac.ir; skh_hosseini@yahoo.com

(Received: 2 December 2011;

Accepted: 25 August 2012)

AJC-12012

\begin{abstract}
In this study, extractives from the heartwood of Robinia pseudoacacia L. (black locust), which was cultivated in the arid region of Iran, were obtained by two steps of extraction. In one step of extraction, fresh wood meal sample was inserted in a balloon and its extractives have been eliminated with $n$-hexane solvent. In the second step of extraction, the extracted wood meal residue was inserted in ethanol solvent at ambient temperature. The chemical compositions of two extractives were analyzed by gas chromatography-mass spectrometry (GC/MS). The comparison extraction extracts has shown that the major components in the $n$-hexane extract mainly to be contained the hexadecanoic acid, trimethylsilyl ester (13.39\%), (Z,Z)-9,12-octadecadienoic acid (10.10\%), tetradecane $(6.88 \%)$, bis $(2-$ ethylhexyl)phthalate $(6.21 \%)$ and hexadecane $(6.15 \%)$, while the major components in the ethanol extract are resorcinol (51.96 \%), (Z,Z,Z)-9,12,15-octadecatrien-1-ol, (6.27 \%), hexadecanoic acid (6.06 \%) and (Z,Z)-9,12-octadecadienoic acid (4.08\%). The same components present in the two different extracts also contained amounts of the octadecane, hexadecanoic acid, ethyl ester, (Z,Z)-9,12octadecadienoic acid, linoleic acid ethyl ester and (Z,Z,Z)-9,12,15-octadecatrienoic acid.
\end{abstract}

Key Words: Heartwood extractives, Chemical composition, Robinia pseudoacacia L., Hexadecanoic acid, Trimethylsilyl ester, 1,3Benzenediol.

\section{INTRODUCTION}

The extractives of trees are among the many classes of compounds known as secondary or special metabolites ${ }^{1}$. The concentrations of these metabolites vary between in softwood and hardwood and also among wood species from tree to tree and from season to season which can be classified according to their morphological site and function in the tree and according to their polarity and solubility in different solvents ${ }^{2,3}$. They present numerous challenges to utilization of trees and numerous opportunities for adding value to forest products such as adhesive, preservatives, food, perfume sector, pharmaceuticals and pharmacological applications ${ }^{4}$.

The compounds within the extractives that play a main role in the protection of the tree against pathogens or other biotic attacks, which their presence is responsible for the natural durability of solid wood ${ }^{5}$.

The genus Robinia of the family Legominoseae is considered as one of the most planted, fast-growing deciduous hardwood tree species which have been a kind of quality wood of multiple industrial purposes due to the valuable trait in stiffness, wear resisting and high basic density. This species is widely distributed throughout the temperate and Mediterranean zones of world.
Generally, the sapwood zone of black locust is quite narrow and most parts of the cross section area are heartwood. The colour of sapwood is yellowish and the heartwood is dark green or olive drab and both of them are inclined to colour variation during drying.

Black locust (R. pseudoacacia L.) is one such potential species, a nitrogen fixing tree ${ }^{6,7}$, native to the south-eastern part of north America ${ }^{8}$ and is a commonly used species for afforestation projects in arid and semi arid regions of Iran due to its soil rehabilitation capabilities. In Iran for instance, $c a .90 \%$ of the total land area of the country is covered by arid or semi arid areas ${ }^{9}$ and Afforestation projects are a frequent approach to control desertification in arid zones in many countries ${ }^{10}$. Plantations with $\mathrm{N}$ fixing trees can generally influence soil fertility but also improve the growth of associated trees positively by enriching $\mathrm{N}$ and organic matter including other nutrients such as phosphorus ${ }^{11}$.

$R$. pseudoacacia L., which is a plant, was chosen for the extraction studies and this plant species contains a large amount of extract ${ }^{12,13}$. Among the extractive compounds tannins, flavonoids (e.g. robtein, butein, etc.), flavanones, flavanonols (e.g. dihydrorobinetin), flavonols (e.g. robinetin), stigmasterol, choline, syringenin, starch, simple sugars, water-soluble proteins and related metabolites have been identified ${ }^{3}$. 
Meszaros et al. ${ }^{14}$ in the performed studies on the composition, thermal behaviour of extractive components of $R$. pseudoacacia L., have been used the thermogravimetry/mass spectrometry (TG/MS), pyrolysis-gas chromatography/mass spectrometry (Py-GC/MS) and methylation-gas chromatography/mass spectrometry (THM-GC/MS) methods and were compared the extraction procedures. They have shown that the quality of the solvent and the extraction time significantly influence the amount of extract eliminated from the plant sample and all the applied solvents (ethanol, acetone and dichloromethane) were capable of removing the phytosterols from the wood. However, fatty acid esters remained in the extracted wood samples in significant amounts even after successive extraction by dichloromethane, ethanol and water.

Meszaros et al. ${ }^{14}$ generally showed that the chemical composition in the ethanol and acetone extracts from the Py-GC/MS experiments have been include benzoic acid, methyl-inositol, neophitadiene, $n$-hexadecanoic acid, 9,12octadecanoic acid, isomer of octadecanoic acid, 1-docosane, $n$-docosane, 1 -tetracosane, $n$-tetracosane, 1 -pentadecane, $n$ pentadecane, $n$-docosanoic acid, 1-hexacosane, hydrocarbon compound and $n$-nonacosane. The identified chemical composition in the wood extract from the THM-GC/MS experiments have been include $n$-dodecanoic acid methyl ester, nonanedioic acid dimethyl ester, $n$-tetradecanoic acid methyl ester, $n$-hexadecanoic acid methyl ester, 9-octadecenoic acid methyl ester, n-octadecanoic acid methyl ester, 9,12-octadecadienoic acid methyl ester, 6,9-octadecadienoic acid methyl ester, 10,13octadecadienoic acid methyl ester, $n$-nonadecenoic acid methyl ester, tridecandioic acid dimethyl ester, $n$-eicosanoic acid methyl ester, 9,12-octadecadienoic acid, hydrocarbon, $n$-docosanoic acid methyl ester, $n$-tricosanoic acid methyl ester, $3,3^{\prime}, 4,4^{\prime}$-tetramethoxy-stilbene, $n$-tetracosanoic acid methyl ester, cis-13-docosenoic acid, alkene, docosandioic acid dimethyl ester and $n$-hexacaosanoic acid methyl ester.

Magel et al. ${ }^{15}$ determined three dominant heartwood extractives in the trunkwood of $R$. pseudoacacia $\mathrm{L}$. and the results showed that all trunks exhibited the highest contents of non-structural storage carbohydrates (glucose, fructose, sucrose and starch) in the outermost sapwood zone and the levels of carbohydrates decreased with increasing depth of the trunk ${ }^{15}$. A very low amount of the flavanonol dihydrorobinetin (DHR) is present in the younger sapwood of $R$. pseudoacacia L. Higher amounts of DHR and the hydroxyl cinnamic acid derivative (HCA) were found in the sapwood-heartwood transi-tion zone. DHR increased within the heartwood. HCA increased towards the heartwood and decreased again in the inner heartwood parts. Flavonol robinetin (ROB) appeared in the innermost parts of the sapwood-heartwood transition zone and reached maximum values in older parts of the heartwood ${ }^{15}$. Early work has shown the presence of stigmasterol, choline, syringenin, starch and simple sugars and related metabolites.
Roux and Paulus ${ }^{16}$ identified 14 flavonoids from the $\mathrm{MeOH}$ extract of the heartwood using paper chromatography, most notably robinetin $\left(3,7,3^{\prime}, 4^{\prime}, 5^{\prime}\right.$-pentahydroxy flavonol) and dihyrorobinetin $\left(3,7,3^{\prime}, 4^{\prime}, 5^{\prime}\right.$-pentahydroxydihydroflavonol). Besides, Smith et al. ${ }^{17}$ claim that remarkable decay resistance of the heartwood of black locust is due to high flavonoid concentrations (6\% of dry weight), specifically the constituents, robtin $(15,000 \mathrm{ppm})$, robinetin $(20,000$ to $80,000 \mathrm{ppm})$ and dihydrorobinetin $(53,000$ to $176,000 \mathrm{ppm})$ and other, flavonoids present in the heartwood are known butein, butin, fisetin, fustin and liquiritigenin ${ }^{18}$.

In the recent decades, the black locust has been started to be cultivated in the arid part of Iran. So far, less ${ }^{19}$ or no study has been done on the chemical composition of black locust cultivated in Iran. Therefore, in this study it was aimed at determining the chemical composition of the black locust cultivated in Iran.

\section{EXPERIMENTAL}

Robinia is planted in nearly all arid and semi-arid Afforestation projects of Iran. After pre-selection of available Robinia stand in location of Karaj, one tree of Robinia was chosen for this investigation. The selected study site was located in same climatic condition in terms of amount of precipitation, average temperature and elevation. Using the $\mathrm{FAO}^{20}$, the Karaj study site is classified as arid area. According to Dawan and Famouri ${ }^{21}$ soil in Karaj is characterized as calcareous Lithosol. It is supposed that this study site is representative for arid area in Iran. Climatic data of the study site was provided by the Iran Meteorological Organization for 40 years from 1965 to 2005 (Table-1).

Preparation of extractives: In this study, the extractives of black locust (Robinia pseudoacacia L.), which was cultivated in the arid region of Iran, were obtained from the fresh heartwood sample. The heartwood sample was milled to a very fine homogenous composition and ground to a fine powdery mixture. The extractives of wood meal sample were extracted by two steps of extraction (Maceration technique). In first step, fresh heartwood meal sample $(10 \mathrm{mg}$ ) was inserted in a $200 \mathrm{~mL}$ balloon and its extractives have been eliminated with $n$-hexane solvent $(150 \mathrm{~mL})$. In the second step, the extracted heartwood meal residue (Slag) was inserted in ethanol solvent $(150 \mathrm{~mL})$. Every one of steps of extraction to take a 15 days long time at ambient temperature and its chemical compositions were analyzed by GC-MS. Extracts from the $n$-hexane and ethanol were dried by evaporating the solvent at $40{ }^{\circ} \mathrm{C}$ until a viscous deposit was left in the flask, then the extracts were dried over anhydrous sodium sulfate and stored at $-18^{\circ} \mathrm{C}$.

Chemical analysis: In order to identify components of extracts, trimethylsilylation was achieved by heating $1 \mathrm{mg}$ of sample at $70^{\circ} \mathrm{C}$ for $1 \mathrm{~h}$ with $30 \mu \mathrm{L}$ bis(trimethylsilyl)trifluoroacetamide (BSTFA) with $10 \mu \mathrm{L}$ of trimethylchlorosilane and $30 \mu \mathrm{L}$ pyridine.

TABLE-1

BASIC SITE CONDITIONS FOR SELECTED AREA

\begin{tabular}{cccccccc}
\hline \multirow{2}{*}{ Study site } & \multirow{2}{*}{ Elevation $(\mathrm{m})$} & \multirow{2}{*}{ Latitude } & \multirow{2}{*}{ Longitude } & \multicolumn{3}{c}{ Annual temperature $\left({ }^{\circ} \mathrm{C}\right)$} & \multicolumn{3}{c}{ Annual } \\
\cline { 5 - 7 } & & & & Min. & Max. & Average & precipitation (mm) \\
\hline Karaj & 1275 & $35^{\circ} 44^{\prime} \mathrm{N}$ & $51^{\circ} 10^{\prime} \mathrm{E}$ & 8.7 & 21.2 & 15.7 & 243.8 \\
\hline
\end{tabular}


The $n$-hexane and ethanol extractives were analyzed on an Agillent 5975B mass spectrometer coupled with a HewlettPackard GC-6890N series GC by using a HP-5MS (5 \% phenyl methyl siloxane) fused silica capillary column $(30 \mathrm{~m} \times 0.25$ mm i.d., $0.25 \mu \mathrm{m}$ film thicknesses) with Agilent 19091J-133 model number. Helium having a flow rate of $1 \mathrm{~mL} / \mathrm{min}$, was used as carrier gas. The GC oven temperature was kept at $50{ }^{\circ} \mathrm{C}$ for $5 \mathrm{~min}$ and programmed to $250{ }^{\circ} \mathrm{C}$ at a rate of $20^{\circ} \mathrm{C} / \mathrm{min}$ and then kept at $250{ }^{\circ} \mathrm{C}$. The injector temperature was $250^{\circ} \mathrm{C}$. The amount of injection was $1 \mu \mathrm{L}$. The carrier gas was delivered at a constant pressure of 7.35 psi. MS spectra were taken at $\mathrm{E} 1$ ion source of $70 \mathrm{eV}$. Identification of the components was based on comparison of their mass spectra with those of internal (computer) library, NIST libraries and some reference compounds. The identification of the chemical constituents was assigned on the basis of comparison of their retention indices and mass spectra with those given in the literature ${ }^{22-24}$. Retention indices (RI) were determined with reference to a homologous series of normal alkanes, by using the following formula ${ }^{25}$.

$$
\begin{aligned}
\mathrm{RI}= & 100[(\mathrm{n}+(\mathrm{N}-\mathrm{n}) \times \log \mathrm{t} 1 \mathrm{R}(\mathrm{x})-\log \mathrm{t} 1 \mathrm{R}(\mathrm{Cn}) / \\
& \log \mathrm{t} 1 \mathrm{R}(\mathrm{CN})-\log \mathrm{t} 1 \mathrm{R}(\mathrm{Cn})]
\end{aligned}
$$

where RI is the retention index of the compound of interest, $\mathrm{t} 1 \mathrm{R}$ is the net retention time ( $\mathrm{tR}-\mathrm{t} 0$ ), $\mathrm{t} 0$ is the retention time of solvent (dead time), $\mathrm{tR}$ is the retention time of the compound of interest, $\mathrm{Cn}$ and $\mathrm{CN}$ are No. of carbons in the $n$-alkanes eluting immediately before and after the compound of interest, $\mathrm{N}$ and $\mathrm{n}$ are the number of carbon atoms in the $n$-alkane eluting immediately before and after the compound of interest.

\section{RESULTS AND DISCUSSION}

The total ion chromatograms of the $n$-hexane and ethanol extractives by GC/MS are shown in Figs. 1 and 2, respectively. Relative content of each component was counted by area normalization. The MS data and the NIST standard MS map were analyzed by computer, open-published books and papers. It was also shown that in the obtained peaks from the $n$-hexane and ethanol extractives (Figs. 1 and 2) were found 28 and 14 compounds which $90.20 \%$ and $85.65 \%$ of the total 39 and 28 peaks areas were identified (Tables 2 and 3).

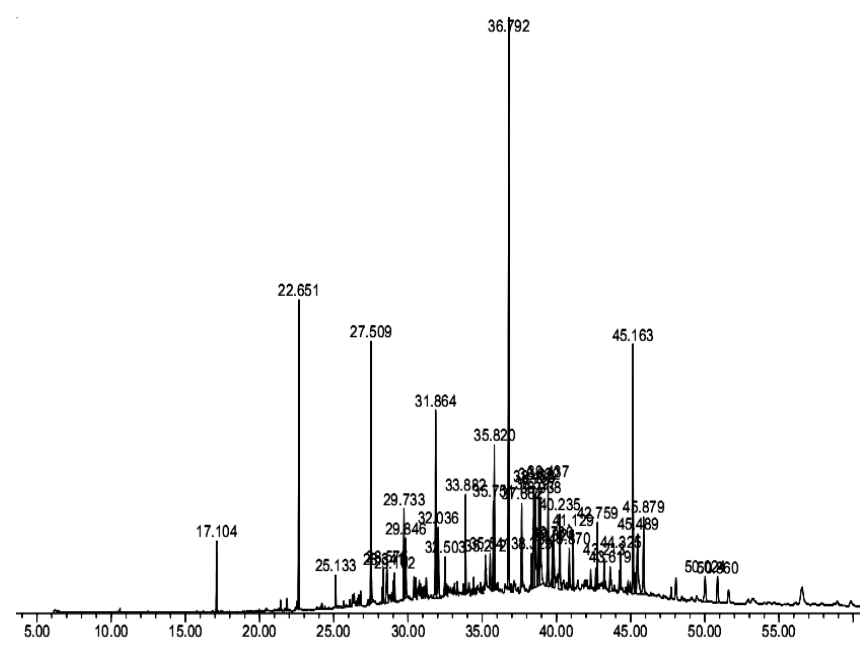

Fig. 1. Total ion chromatogram of $n$-hexane extractive of black locust heartwood by GC/MS

TABLE-2

\begin{tabular}{|c|c|c|c|c|c|c|}
\hline No. & Compound & m.w. & m.f. & $\mathrm{RT}^{\mathrm{a}}$ & $\mathrm{KI}^{\mathrm{b}}$ & Area $(\%)$ \\
\hline 1 & Dodecane & 170 & $\mathrm{C}_{12} \mathrm{H}_{26}$ & 17.104 & 1199 & 1.39 \\
\hline 2 & Tetradecane & 198 & $\mathrm{C}_{14} \mathrm{H}_{30}$ & 22.651 & 1401 & 6.88 \\
\hline 3 & Pentadecane & 212 & $\mathrm{C}_{15} \mathrm{H}_{32}$ & 25.133 & 1500 & 0.66 \\
\hline 4 & Hexadecane & 226 & $\mathrm{C}_{16} \mathrm{H}_{34}$ & 27.509 & 1601 & 6.15 \\
\hline 5 & 5-Phenyl-undecane & 232 & $\mathrm{C}_{17} \mathrm{H}_{28}$ & 28.339 & 1639 & 0.70 \\
\hline 6 & 4-Phenyl-undecane & 232 & $\mathrm{C}_{17} \mathrm{H}_{28}$ & 28.572 & 1650 & 1.64 \\
\hline 7 & Hexadecamethyl-cyclooctasiloxane & 593 & $\mathrm{C}_{16} \mathrm{H}_{48} \mathrm{O}_{8} \mathrm{Si}_{8}$ & 29.102 & 1673 & 0.72 \\
\hline 8 & Heptadecane & 240 & $\mathrm{C}_{17} \mathrm{H}_{36}$ & 29.733 & 1701 & 1.93 \\
\hline 9 & 2,6,10,14-Tetramethyl pentadecane & 268 & $\mathrm{C}_{19} \mathrm{H}_{40}$ & 29.846 & 1706 & 1.78 \\
\hline 10 & Octadecane & 254 & $\mathrm{C}_{18} \mathrm{H}_{38}$ & 31.864 & 1801 & 4.26 \\
\hline 11 & 2,6,10,14-Tetramethyl-hexadecane & 282 & $\mathrm{C}_{20} \mathrm{H}_{42}$ & 32.036 & 1810 & 2.69 \\
\hline 12 & Nonadecane & 268 & $\mathrm{C}_{19} \mathrm{H}_{40}$ & 33.882 & 1901 & 3.16 \\
\hline 13 & Hexadecanoic acid, ethyl ester & 284 & $\mathrm{C}_{18} \mathrm{H}_{36} \mathrm{O}_{2}$ & 35.752 & 1998 & 2.08 \\
\hline 14 & Eicosane & 282 & $\mathrm{C}_{20} \mathrm{H}_{42}$ & 35.820 & 2002 & 3.08 \\
\hline 15 & Hexadecanoic acid, trimethylsilyl ester & 328 & $\mathrm{C}_{19} \mathrm{H}_{40} \mathrm{O}_{2} \mathrm{Si}$ & 36.792 & 2055 & 13.39 \\
\hline 17 & (Z,Z)-9,12-Octadecadienoic acid & 280 & $\mathrm{C}_{18} \mathrm{H}_{32} \mathrm{O}_{2}$ & 38.488 & 2149 & 10.10 \\
\hline 18 & Linolenic acid, ethyl ester & 308 & $\mathrm{C}_{20} \mathrm{H}_{36} \mathrm{O}_{2}$ & 38.825 & 2168 & 2.84 \\
\hline 19 & $(Z, Z, Z)-9,12,15-O c t a d e c a t r i e n o i c ~ a c i d$, ethyl ester & 306 & $\mathrm{C}_{20} \mathrm{H}_{34} \mathrm{O}_{2}$ & 38.935 & 2174 & 3.10 \\
\hline 20 & Docosane & 310 & $\mathrm{C}_{22} \mathrm{H}_{46}$ & 39.439 & 4189 & 2.99 \\
\hline 21 & Octadecanoic acid, trimethylsilyl ester & 356 & $\mathrm{C}_{21} \mathrm{H}_{44} \mathrm{O}_{2} \mathrm{Si}$ & 40.235 & 2250 & 2.73 \\
\hline 22 & Octadecamethyl-cyclononasiloxane & 667 & $\mathrm{C}_{18} \mathrm{H}_{54} \mathrm{O}_{9} \mathrm{Si}_{9}$ & 40.869 & 2287 & 0.95 \\
\hline 23 & Tricosane & 324 & $\mathrm{C}_{23} \mathrm{H}_{48}$ & 41.129 & 2302 & 1.37 \\
\hline 24 & Tetracosane & 338 & $\mathrm{C}_{24} \mathrm{H}_{50}$ & 42.759 & 2402 & 1.66 \\
\hline 25 & DehydroAbietic acid & 314 & $\mathrm{C}_{20} \mathrm{H}_{28} \mathrm{O}_{2}$ & 43.619 & 2457 & 1.17 \\
\hline 26 & Bis(2-ethylhexyl) phthalate & 340 & $\mathrm{C}_{24} \mathrm{H}_{38} \mathrm{O}_{4}$ & 45.163 & 2556 & 6.21 \\
\hline 27 & Docosanoic acid & 340 & $\mathrm{C}_{22} \mathrm{H}_{44} \mathrm{O}_{2}$ & 45.489 & 2577 & 3.30 \\
\hline 28 & $(2,6,10,15,19,23$-Hexamethyl,2,6,10,14,18,22-tetracosahexaene)squalene & 410 & $\mathrm{C}_{30} \mathrm{H}_{50}$ & 50.863 & 2832 & 1.17 \\
\hline
\end{tabular}

COMPONENTS OF THE $n$-HEXANE EXTRACT FROM $R$. pseudoacacia L. HEARTWOOD BY GC/MS ANALYSIS 
TABLE-3

COMPONENTS OF THE ETHANOL EXTRACT FROM $R$. pseudoacacia L. HEARTWOOD BY GC/MS ANALYSIS

\begin{tabular}{|c|c|c|c|c|c|c|}
\hline No. & Compound & m.w. & m.f. & $\mathrm{RT}^{\mathrm{a}}$ & $\mathrm{KI}^{\mathrm{d}}$ & Area $(\%)$ \\
\hline 1 & 5-Methyl-2-(1-methylethyl)phene & 150 & $\mathrm{C}_{10} \mathrm{H}_{14} \mathrm{O}$ & 20.405 & 1317 & 1.47 \\
\hline 2 & Resorcinol & 110 & $\mathrm{C}_{6} \mathrm{H}_{6} \mathrm{O}_{2}$ & 21.118 & 1345 & 51.96 \\
\hline 3 & 1-(2,4-Dihydroxyphenyl)ethanone & 152 & $\mathrm{C}_{8} \mathrm{H}_{8} \mathrm{O}_{3}$ & 27.279 & 1592 & 2.87 \\
\hline 4 & 9-Methylnonadecane & 282 & $\mathrm{C}_{20} \mathrm{H}_{42}$ & 27.485 & 1600 & 1.63 \\
\hline 5 & Octadecane & 254 & $\mathrm{C}_{18} \mathrm{H}_{38}$ & 31.847 & 1800 & 0.39 \\
\hline 6 & Methyldibenzothiophene & 198 & $\mathrm{C}_{13} \mathrm{H}_{10} \mathrm{~S}$ & 33.030 & 1860 & 0.36 \\
\hline 7 & Hexadecanoic acid & 256 & $\mathrm{C}_{16} \mathrm{H}_{32} \mathrm{O}_{2}$ & 35.256 & 1973 & 6.06 \\
\hline 9 & $(\mathrm{Z}, \mathrm{Z})-9,12-$-Octadecadienoic acid & 280 & $\mathrm{C}_{18} \mathrm{H}_{32} \mathrm{O}_{2}$ & 38.424 & 2145 & 4.08 \\
\hline 10 & (Z,Z,Z)-9,12,15-Octadecatrien-1-ol & 264 & $\mathrm{C}_{18} \mathrm{H}_{32} \mathrm{O}$ & 38.545 & 2152 & 6.27 \\
\hline 11 & Linoleic acid ethyl ester & 308 & $\mathrm{C}_{20} \mathrm{H}_{36} \mathrm{O}_{2}$ & 38.810 & 2167 & 2.29 \\
\hline 12 & $(Z, Z, Z)-9,12,15$-Octadecatrienoic acid, ethyl ester & 306 & $\mathrm{C}_{20} \mathrm{H}_{34} \mathrm{O}_{2}$ & 38.921 & 2173 & 2.98 \\
\hline 13 & Bis(2-ethylhexyl) phthalate & 390 & $\mathrm{C}_{24} \mathrm{H}_{38} \mathrm{O}_{4}$ & 45.144 & 2555 & 3.40 \\
\hline 14 & 2-Methoxy-5-(2',3'-dimethoxyphenyl)cyclohepta-2,4,6-trien-1-one & 272 & $\mathrm{C}_{16} \mathrm{H}_{16} \mathrm{O}_{4}$ & 47.228 & 2675 & 0.84 \\
\hline
\end{tabular}

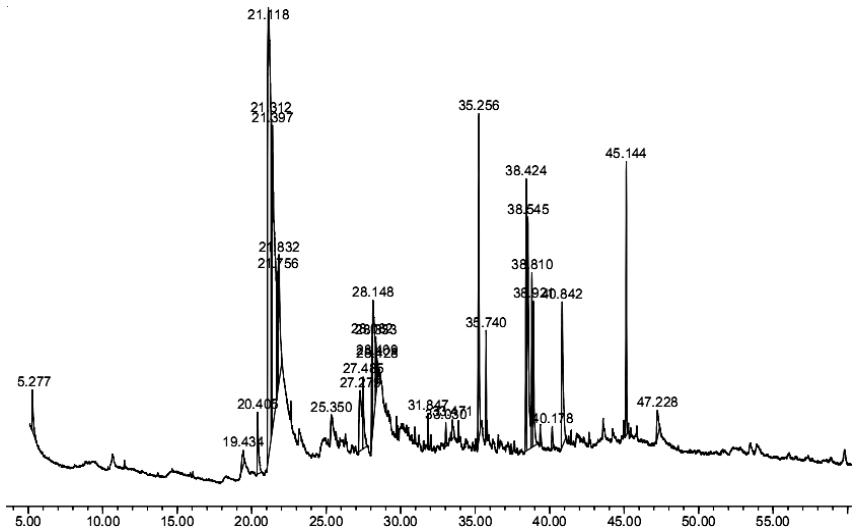

Fig. 2. Total ion chromatogram of ethanol extractive of black locust heartwood by GC/MS

Generally the chemical compositions present in the $n$ hexane and ethanol extracts have been including volatile compounds such as: acids, fatty acids, aliphatic hydrocarbons, aromatic hydrocarbons, esters, fatty acids ester, pure hydrocarbon oils or mineral oils ${ }^{26,27}$, alcohol aliphatic, etc.

Since present results report all of the values; however some of these components that also are very important were first reported in this study.

In previous studies, was found the same components in the extractives of black locust (Robinia pesudoacacia L.) ${ }^{14}$, but some of components such as tannins, flavonoids (e.g. robtein, butein, etc.), flavanones, flavanonols (e.g. dihydrorobinetin), flavonols (e.g. robinetin), stigmasterol, choline, syringenin, starch, simple sugars, water-soluble proteins and related metabolites that previously were reported ${ }^{3,15-18}$ were not found in the $n$-hexane and ethanol extracts. It can be claim that wood species, provenance conditions, type of extraction solvent, process, technique and time is remarkably important to remove these components.

Since our results reported all of the components; however some of these components that also are very important were first time reported in this study.

\section{Conclusion}

The chemical composition of black locust heartwood extractives provided from the Karaj site in Iran was investigated. $n$-hexane and ethanol extracts from black locust (Robinia pseudoacacia L.) cultivated in the arid region of Iran, was obtained from maceration extraction method and its chemical composition was determined by GC-MS.

The principal and valuable components of the $n$-hexane and ethanol extractives of black locust (Robinia pseudoacacia L.) heartwood by GC/MS analysis were hexadecanoic acid, trimethylsilyl ester (13.39\%), 9,12-octadecadienoic acid (Z,Z)- (10.10\%), tetradecane (6.88\%), bis(2-ethylhexyl) phthalate $(6.21 \%)$, hexadecane $(6.15 \%)$, resorcinol $(1,3-$ benzendiol) (51.96\%), 9,12,15-octadecatrien-1-ol, (Z,Z,Z)$(6.27 \%)$, hexadecanoic acid $(6.06 \%)$ and 9,12-octadecadienoic acid (Z,Z)- (4.08\%).

\section{ACKNOWLEDGEMENTS}

The author is grateful to Islamic Azad University, Karaj Branch for the financial support of the research project. Thanks are also due to Dr. Irani, Dr. Ghare-vaysi, Dr. Mirabi and Mr. Miri (Research of Islamic Azad University, Ghaemshahr Branch) for using the laboratory equipments and special thanks to Mrs. Azimi (operator of GC/MS apparatus) for helping in the injection of test samples and $n$-alkanes sample.

\section{REFERENCES}

1. O.R. Gottlieb, Phytochemistry, 29, 1715 (1990).

2. B. Holmbom, in eds.: E. Sjöström and R. Alen, Extractives, in Analytical Methods in Wood Chemistry, Pulping and Papermaking, Springer, Berlin, pp. 125-147 (1999).

3. J.W. Rowe and A.H. Conner, Extractives in Eastern Hardwoods, A Review, Gen. Tech. Rep. FPL-18, Madison, WI: U.S. Department of Agriculture, Forest Service, Forest Products Laboratory, p. 67 (1979).

4. M. Winks and O. Schimmer, Modes of Action of Defensive Secondary Metabolites, Function of Plant SMs and Their Exploitation in Biotechnology, Annual Plant Reviews, pp. 17-133, Sheffield Academic Press, Sheffield (1999).

5. H. Pereira, J. Graca and J.C. Rodrigues, in eds.: J.R. Barnett and G. Jeronimidis, Wood Chemistry in Relation to Wood Quality, In Wood Quality and Its Biological Basis, Biological Sciences Series, Blackwell Publishing \& CRC Press, pp. 53-86 (2003).

6. J.W. Hanover, K. Miller and S. Plesko, in eds.: J.W. Hanover, K. Miller and S. Plesko, Black Locust: An Historical and Future Perspective, 718, Black Locust: Biology, Culture and Utilization, Proceedings International Conference Black Locust, East Lansing, MI, USA (1992).

7. H.S. Moon, S.Y. Jung and S.C. Hong, Korean J. Ecol., 24, 371 (2001). 
8. R.P. Barrette, T. Mebrahtu and J.W. Hanover, in eds.: J. Janick and J. Simon, Black Locust: A Multipurpose Tree Species for Temperate Climates, In: Advances in New Crops, Timber Press, Portland, pp. 278$283(1990)$

9. S.A. Chavoshian, An Overview to Trans Boundary and Shared Water Resources Management in Iran, Technical Challenges and Solutions, Proceedings of the International Conference on Role of Water Sciences in Trans Boundary River Basin Management, (ICRWSTBRBM'05), Thailand, pp. 189-195(2005).

10. M. Kassas, J. Arid Environ., 30, 115 (1995).

11. J.S. Wang, S.A. Khan and J.O. Dawson, Nitrogen fixing trees influence concentration of ammonium and amino sugar-nitrogen in soils, Proceeding of the 9th North American Agro-forestry Conference, June 12-15, University of Illinois, pp. 1-17 (2005).

12. P. Chow, G.L. Rolfe and T.F. Shupe, Wood Fiber Sci., 28, 186 (1996).

13. J.B. Harborne, Nature, 200, 1055 (1963).

14. E. Meszaros, E. Jakab and G. Varhegyi, J. Anal. Appl. Pyrol., 79, 61 (2007).

15. E. Magel, C. Jay-Allemand and H. Ziegler, Trees Struct. Funct., 8, 165 (1994).

16. D.G. Roux and E. Paulus, Biochem. J., 82, 324 (1962).

17. A.L. Smith, C.L. Campbell, M.P. Diwakar, J.W. Hanover and R.O. Miller, Holzforschung, 43, 293 (1989)
18. J.A. Duke, Dr. Duke's Phytochemical and Ethnobotanical Databases, [Online] Available at (http://www.ars-grin.gov/duke/), (posted 10 March 1998) (2000)

19. F. Sefidkon, A. Agha-Vali Jamaat, M.A. Rudsari and K. Jimand, Iran. J. Med. Arom. Plants Res., 20, 19 (2004).

20. FAO, Improving Productivity of Dry Land Areas, Committee on Agriculture (Ninth Session), FAO, Rome (1987).

21. M.L. Dawan and J. Famouri, The Soils of Iran, Food and Agriculture Organization of the United Nations, Iran (1964).

22. R.P. Adams, Identification of Essential Oil Components by Gas Chromatography/Mass Spectrometry, Allured Publishing Co., Illionis, USA., ISBN, edn. 1 (1995).

23. R.P. Adams, Identification of Essential Oils Components by Gas Chromatography Quadrupole Mass Spectrometry, Allured Publishing Co., Illionis, USA., ISBN, edn. 1 (2001).

24. D. Julian and W.A. Konig, The Atlas of spectral Data of Sesquiterpene Hydrocarbons, E.B. Verlag, Harburg (1988).

25. E. Kovats, Helv. Chim. Acta, 41, 1915 (1958).

26. M. Satoh, Y. Kuroda, H. Yoshida, K.M. Behney, A. Mizutani and J. Akaogi, J. Autoimmun., 21, 1 (2003).

27. Y. Kuroda, J. Akaogi, D.C. Nacionales, W.H. Reeves and M. Satoh, Toxicol. Sci., 78, 222 (2004). 